SSESSMENTS FOR THE
STRATION ACCELERATOR, 1996

\author{
by Saul Cross
}

RECEIVED

FEB 141997

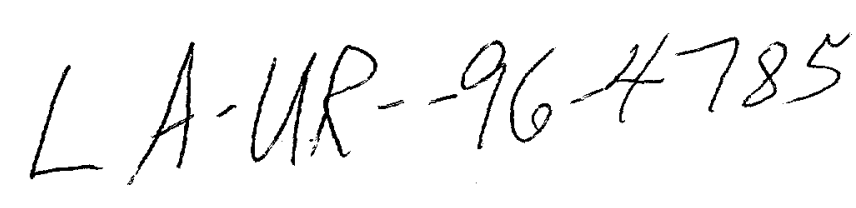

OSTI

This report was prepared as an account of work sponsored by an agency of the United States Government. Neither the United States Government nor any agency thereof, nor any of their employees, makes any warranty, express or implied, or assumes any legal liability or responsibility for the accuracy, completeness, or usefulness of any information, apparatus, product, or process disclosed, or represents that its use would not infringe privately owned rights. Reference herein to any specific commercial product, process, or service by trade name, trademark, manufacturer, or otherwise does not necessarily constitute or imply its endorsement, recommendation, or favoring by the United States Government or any agency thereof. The views and opinions of authors expressed herein do not necessarily state or reflect those of the United States Government or any agency thereof. 


\section{DISCLAIMER}

Portions of this document may be illegible in electronic image products. Images are produced from the best available original document. 


\section{TABLE OF CONTENTS}

I. ENVIRONMENTAL SETTING 1

1.1 General Setting and Climate 1

1.2 Sandia Canyon 5

1.3 Description of Area to be Affected by LEDA Discharges 10

II. PROJECT DESCRIPTION 12

2.1 The LEDA Project 12

$\begin{array}{ll}2.2 \text { Annual Biological Assessments } & 15\end{array}$

$\begin{array}{ll}\text { III. SOILS } & 16\end{array}$

$\begin{array}{ll}3.1 \text { Hydric Soils } & 16\end{array}$

$\begin{array}{ll}3.2 \text { Soils within the LEDA Drainage } & 19\end{array}$

$\begin{array}{ll}\text { IV. WATER QUALITY } & 21\end{array}$

4.1 Sandia Canyon and Water Quality Standards 21

$\begin{array}{ll}4.2 \text { NPDES Sampling } & 22\end{array}$

V. VEGETATION 22

5.1 Vegetation of LANL 22

5.2 Vegetation of the Project Area 24

VI. WILDLIFE

6.1 Wildlife of LANL $\quad 29$

6.1.1 Invertebrates 29

$\begin{array}{ll}6.1 .2 \text { Fish } & 29\end{array}$

6.1.3 Reptiles and Amphibians $\quad 29$

$\begin{array}{ll}6.1 .4 \text { Birds } & 30\end{array}$

$\begin{array}{ll}\text { 6.1.5 Mammals } & 30\end{array}$

6.2 Wildlife of the Project Area 31

6.2.1 Birds 31

6.2.2 Reptiles and Amphibians $\quad 32$

6.2.3 Large Mammals 33 
VII. THREATENED AND ENDANGERED SPECIES 34

VIII. BIOLOGICAL BEST MANAGEMENT PRACTICES 36

$\begin{array}{ll}\text { IX. CONCLUSIONS } & 37\end{array}$

X. ACKNOWLEDGMENTS 39

XI. GLOSSARY OF ACRONYMS AND TECHNICAL TERMS 40

XII. CITATIONS 43

\section{LIST OF FIGURES}

Fig. 1. Location of Los Alamos National Laboratory, New Mexico. 2

Fig. 2. Location of TA-53 with respect to Laboratory TAs and surrounding lands.

Fig. 3. 1996 monthly precipitation totals for the mid-Sandia Canyon area. 6

Fig. 4. National Wetland Inventory map for Sandia Canyon. 8

Fig. 5. Biological Monitoring Area for the LEDA Project. 17

\section{LIST OF TABLES}

$\begin{array}{ll}\text { Table 1. Soil Pit Locations and Soil Characteristics. } & 20\end{array}$

Table 2. NPDES Limits for Outfall 03A113. 22

Table 3. Dominant Understory Plants in the LEDA Drainage, Transects 1 and 2.

Table 4. Dominant Understory Plants in the LEDA Drainage, Transects 3 and 4.

Table 5. USFWS T\&E Species List for Los Alamos County, March 1996. 
APPENDICES

APPENDIX A. Plant Species within 1996 Vegetation Transects in Mid-Sandia Canyon.

APPENDIX B. Bird Species Found in 1996 Mid-Sandia Canyon Bird Transect.

APPENDIX C. Reptiles and Amphibians Species Captured during the 1996 Trapping Season in Mid-Sandia Canyon. 


\title{
BIOLOGICAL ASSESSMENTS FOR THE \\ LOW ENERGY DEMONSTRATION ACCELERATOR, 1996
}

\author{
by Saul Cross
}

\section{ENVIRONMENTAL SETTING}

\subsection{General Setting and Climate}

The Low Energy Demonstration Accelerator (LEDA) will be sited within the

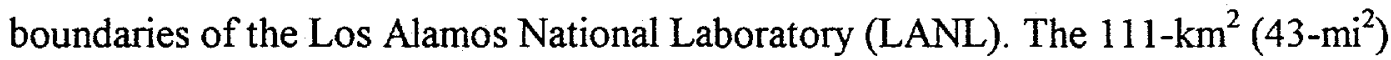
Laboratory site is located in north-central New Mexico on the Pajarito Plateau, approximately $120 \mathrm{~km}(80 \mathrm{mi})$ north of Albuquerque and $40 \mathrm{~km}(25 \mathrm{mi})$ west of Santa $\mathrm{Fe}$

(Fig. 1). In the LANL region, the eastern edge of the Pajarito Plateau descends to the Rio Grande in White Rock Canyon. The Rio Grande flows in a southwesterly direction along the easternmost boundary of LANL.

Most LANL industrial developments are confined to the mesa tops, which range in elevation from a maximum of $2,400 \mathrm{~m}(7,800 \mathrm{ft})$ above sea level (asl) along the western boundary to about $1,900 \mathrm{~m}(6,200 \mathrm{ft})$ asl at their eastern terminus above the Rio Grande. The canyons within LANL boundaries can be as deep as $300 \mathrm{~m}(1,000 \mathrm{ft})$ below the mesa top. LANL is divided into Technical Areas (TAS) that contain administration and support function buildings, experimental and research areas, waste disposal areas, roads, and utility corridors (Fig. 2). However, these components use only a small part of LANL's total land area, and the remainder is reserved as buffer zones and potential sites for future development (EPG 1996). 


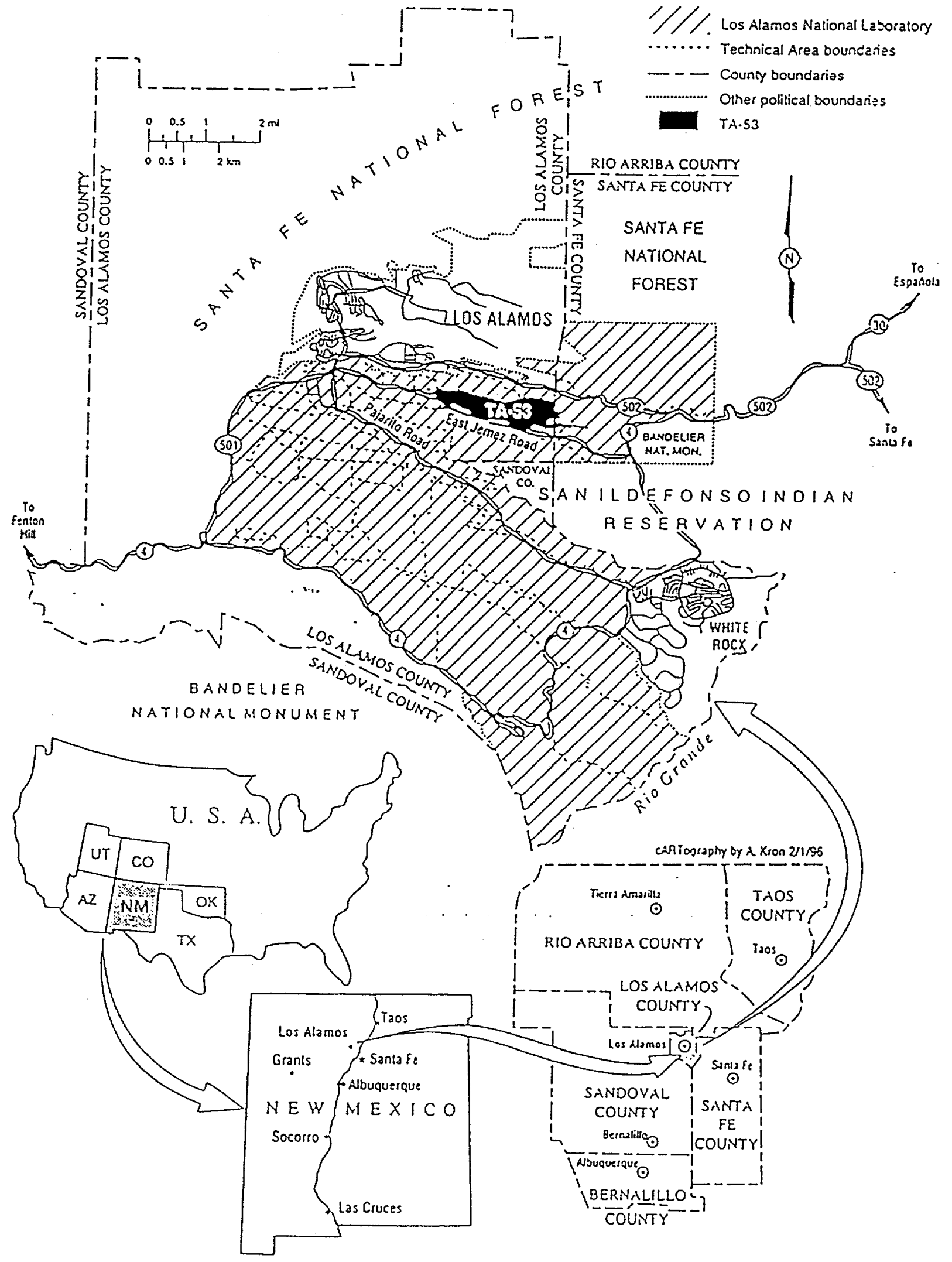

Figure 1. Location of Los Alamos Laboratory. 


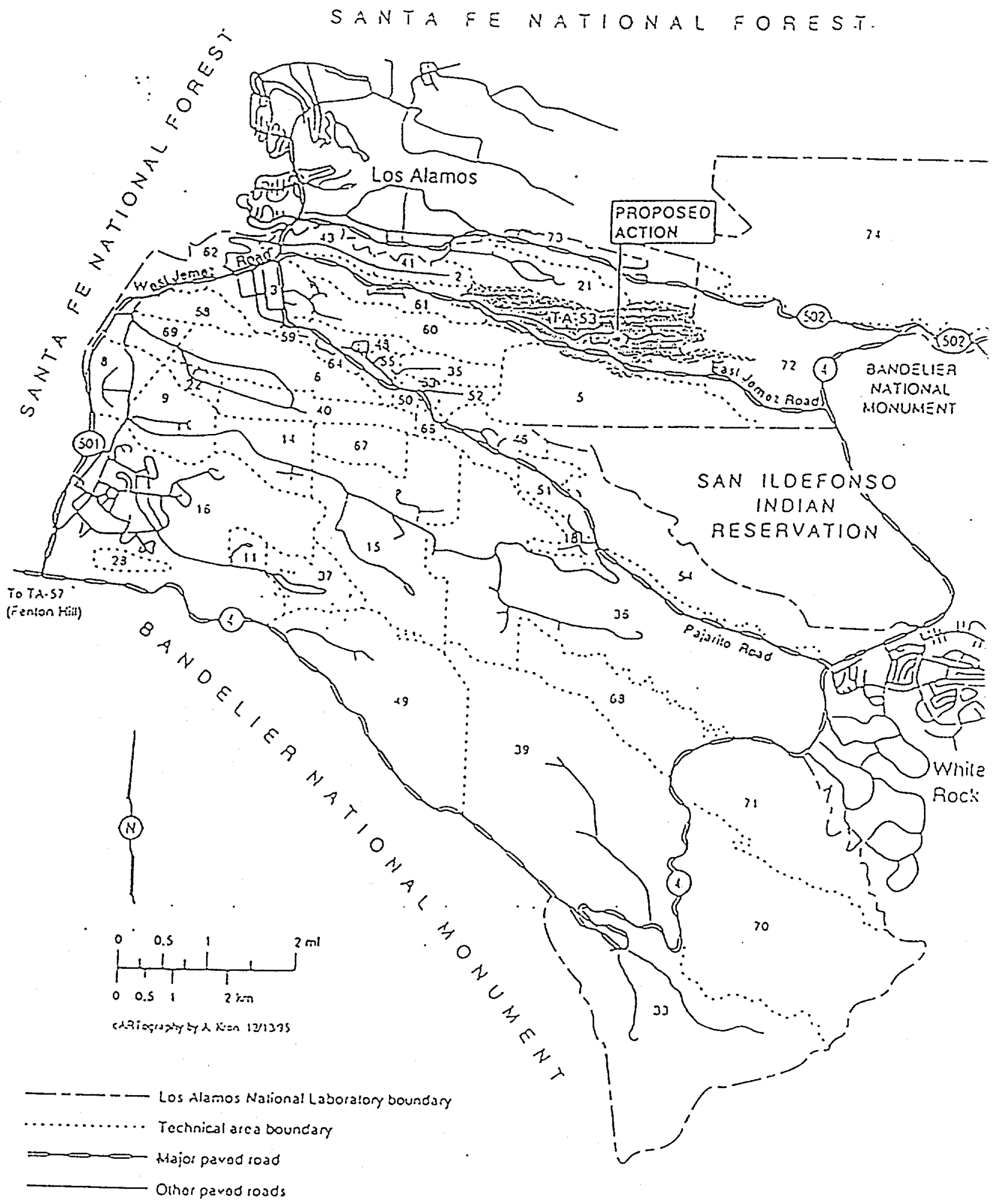

Fig. 2. Location of TA-53 with respect to Laboratory TAs and surrounding lands. 
Most of the mesas in the Los Alamos area are formed from Bandelier Tuff, which includes ash fall, ash fall pumice, and rhyolite tuff. The tuff, ranging from nonwelded to welded, is more than $300 \mathrm{~m}(1,000 \mathrm{ft})$ thick in the western part of the Plateau and thins to about $80 \mathrm{~m}(260 \mathrm{ft})$ eastward above the Rio Grande. It was deposited as a result of major volcanic eruptions in the Jemez Mountains about 1.2 to 1.6 million years ago. The tuff overlaps onto the Tschicoma Formation, which consists of older volcanics that form the Jemez Mountains. In the central and eastern edge along the Rio Grande, the tuff is underlain by the conglomerate of the Puye Formation. Chino Mesa basalts intermix with the conglomerate along the river. These formations overlay the sediments of the Santa Fe Group, which extend across the Rio Grande Valley and are more than $1,000 \mathrm{~m}(3,300 \mathrm{ft})$ thick (EPG 1996).

LANL has a semiarid, temperate mountain climate. The average high temperature in July from 1961 through 1990 was $27^{\circ} \mathrm{C}\left(81^{\circ} \mathrm{F}\right)$, and the average high temperature in January was $4^{\circ} \mathrm{C}\left(40^{\circ} \mathrm{F}\right)$. The average low temperature in July from 1961 through 1990 was $13^{\circ} \mathrm{C}\left(55^{\circ} \mathrm{F}\right)$, and the average low temperature in January was $-8^{\circ} \mathrm{C}\left(17^{\circ} \mathrm{F}\right)$. Daily temperature fluctuations average $13^{\circ} \mathrm{C}\left(23^{\circ} \mathrm{F}\right)$, a result of LANL's high elevation and a dry, clear atmosphere, which allows high insolation during the day and rapid radiative losses at night (EPG 1996).

The average annual precipitation is $48 \mathrm{~cm}$ ( $18.7 \mathrm{in}$.), and the first five years of the 1990s are considered to be normal rainfall years. Approximately 36 percent of the annual precipitation normally occurs during July and August. Runoff from late-summer thundershowers flows through the various canyons, supplementing ground water in the 
shallow alluvium. Winter precipitation falls primarily as snow with accumulations of about $150 \mathrm{~cm}$ (59 in.) (EPG 1996).

\subsection{Sandia Canyon}

Sandia Canyon has three reaches: an upper reach consisting of a cattail (Typha latifolia) marsh and a narrow channel with a coniferous overstory, a middle reach consisting of a usually-dry flat floodplain with a variable overstory, and a lower reach with a coniferous overstory. The first two reaches occur on LANL property, and LEDA effluent releases will eventually be discharged into the mid-canyon reach. The lowest reach occurs primarily on lands belonging to the Pueblo of San Ildefonso and include the confluence of Sandia Canyon with the Rio Grande.

The head of Sandia Canyon is near the University House in TA-3, and the canyon extends southeastward to the Rio Grande. The drainage basin is approximately $13.5 \mathrm{~km}^{2}$ $\left(5.6 \mathrm{mi}^{2}\right)$, and the initial $7.5 \mathrm{~km}(4.7 \mathrm{mi})$ of the canyon occur on LANL property. Industrial effluents from LANL activities maintain a year-round stream flow in upper Sandia Canyon. The lower canyon has seasonal flows, and stream water reaches the Rio Grande only a few days each year due to storm events and snowmelt. Monthly 1996 precipitation totals from the nearest meteorological station (located within the Pajarito Wetlands in TA-53) are shown in Fig. 3.

The National Wetlands Inventory (NWI) conducted by the U.S. Fish and Wildlife Service (USFWS) identified three types of wetlands or water systems within Sandia Canyon (Cowardin et al. 1979). These determinations were made primarily by stereoscopic analysis of high altitude aerial photographs and were not field checked. The aerial photographs typically reflect conditions during the specific year and season when 


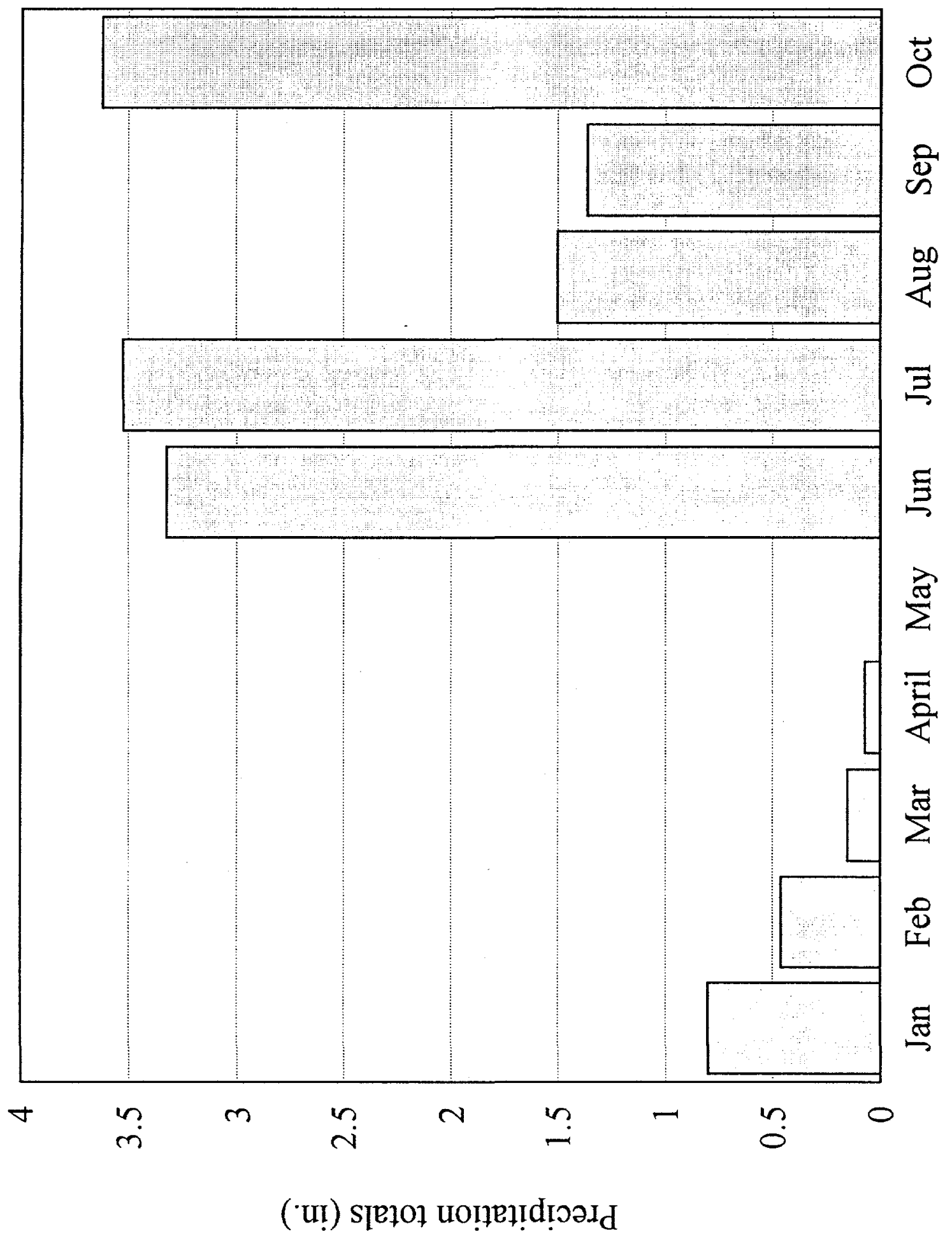

Fig. 3. 1996 monthly precipitation totals for the mid-Sandia Canyon area. 
they were taken. Federal, State, and local regulatory agencies with jurisdiction over wetlands may define and describe wetlands in a different manner than that used in this inventory. According to the NWI, the upper reach in TA-3 is a "persistent, artificially flooded, palustrine wetland." Both upstream and downstream from the project area, "intermittent, temporarily flooded, riverine stream beds" occur within the canyon. The confluence of Sandia Canyon with the Rio Grande has a "permanently flooded, lower perennial riverine wetlands with an unconsolidated bottom." The NWI map of Sandia Canyon is shown in Fig. 4.

The Biology Team of LANL's Ecology Group (ESH-20) has studied upper Sandia Canyon for the last five years. The team currently monitors aquatic macroinvertebrates, habitat suitability, and water quality parameters ( $\mathrm{pH}$, water temperature, dissolved oxygen, and conductivity) in the upper canyon area monthly. Annual status reports (Bennett 1994; Cross 1994, 1995, 1996a) document conditions found within and below a cattaildominated marsh, the largest wetlands on LANL property. These areas occur downgradient from TA-3 and have received effluent discharges from LANL operations since the early 1950 s. A perennial stream flow is currently maintained primarily by discharges from cooling towers below the TA-3 power plant, recirculated water from the Sanitary Waste Systems Consolidation (SWSC) plant, and storm water diversions from TA-3 roads, buildings, and parking lots. A large culvert underneath a demolition landfill empties water from the TA-3 power plant, diverted storm water, and several low-volume LANL outfalls into the head of the canyon. The SWCS 13 S outfall discharges excess reuse water on a southern hillside, approximately $40 \mathrm{~m}(125 \mathrm{ft})$ from the culvert. 


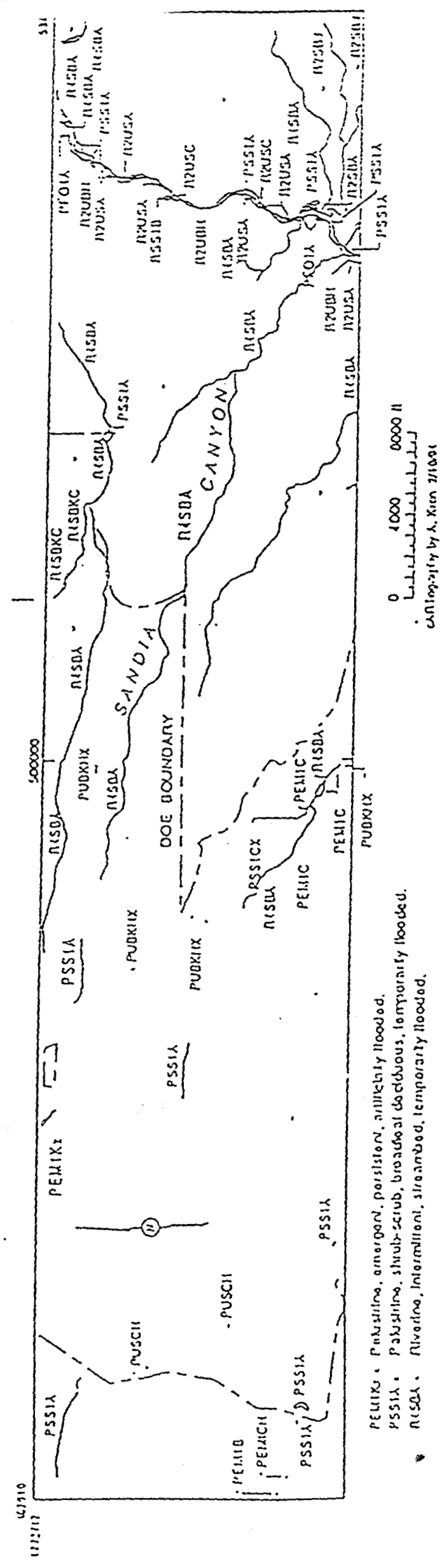

Fig. 4. National Wetland Inventory map for Sandia Canyon. 
Typical flows range between 40 to $60 \mathrm{gpm}$ through the culvert and 100 to 150 gpm through the $13 \mathrm{~S}$ outfall, although storm events tremendously increase these volumes. Waters from both points of discharge commingle in the channel that has cut through soft sediments near the center of the canyon. More accurate and continuous measurements of water flows is required before the magnitude of storm events in the upper canyon area can be quantified.

Downstream from the cattail marsh, the stream passes through an approximately 3.0-km (1.9-mi) stretch of densely shaded narrow canyon. The overstory consists primarily of Douglas-fir (Pseudotsuga menziesii), ponderosa pine (Pimus ponderosa), and white fir (Abies concolor). Several riparian trees and shrubs grow along the stream bank, including coyote willow (Salix exigua), water birch (Betula occidentalis), and Rocky Mountain maple (Acer glabrum).

The stream emerges from the shaded canyon in the TA-53 area. Here, the stream flows within a deep ravine bordered by the precipitous roadbed of East Jemez Road to the north. The southern edge of the stream is a steep hillside densely forested by Douglas-fir, ponderosa pine, and small Gambel oak (Quercus gambelii) trees. The streambed substrate consists primarily of cobbles, gravels, and fine sediments eroded from upstream areas.

The narrow ravine extends for approximately $1.6 \mathrm{~km}(1.0 \mathrm{mi})$ before the drainage enters a large meadow extending on both sides of East Jemez Road in mid-Sandia Canyon. Discharges from the LEDA outfall will enter the canyon near the head of the meadow, where the flat grassy area is approximately $145 \mathrm{~m}(480 \mathrm{ft})$ wide with the road running through its center. Tall $(21 \mathrm{~m}$ or $70 \mathrm{ft})$ sheer tuff cliffs ring the northern edge of the meadow, while the southern edge is more gradual and is well vegetated with coniferous 
trees. The upper meadow has only a few scattered trees, but the overstory is fairly thick downstream, consisting of one-seed juniper (Juniperus monosperma), piñon pine (Pinus edulis), and ponderosa pine trees with a shrub layer of skunkbush (Rhus trilobata) and small Gambel oak. The drainage meanders through this fairly flat section for approximately $4 \mathrm{~km}(2.5 \mathrm{mi})$ until it crosses State Route 4 and enters lands belonging to the Pueblo of San Ildefonso.

\subsection{Description of Area to be Affected by LEDA Discharges}

Cooling water from LEDA operations will be discharged at Outfall $03 \mathrm{~A} 113$ behind buildings 53-293 and 53-294. Effluent from LEDA will be discharged at the mesa's edge and onto a steep hillside on Sandia Canyon's northern side. The area immediately to the east and partially above the outfall is unvegetated and covered with loose fill from road construction. This material covers a steep $12-\mathrm{m}(40-\mathrm{ft})$-high slope, is eroding, and is a source of sediments to the lower portion of the outfall drainage. The point of discharge is a $0.8-\mathrm{m}(2.5-\mathrm{ft})$-wide culvert near an industrial area of buildings, parking lots, and paved roads. This outfall has previously discharged effluents from other TA-53 operations and is permitted under the National Pollutant Discharge Elimination System (NPDES) regulations. A second culvert located $1.5 \mathrm{~m}(5 \mathrm{ft})$ to the west discharges into the same drainage.

Effluent from Outfall 03A113 flows southward onto exposed tuff which has been mechanically scooped out to form a short channel that is $0.8-\mathrm{m}(2.5-\mathrm{ft})$-deep and $0.9-\mathrm{m}$ (3-ft)- wide. The upper reach is fairly level for about $6 \mathrm{~m}(20 \mathrm{ft})$, after which the drainage spreads out as it descends a steep section of tuff for another $7.5 \mathrm{~m}(25 \mathrm{ft})$. The drainage 
then levels out for another $30 \mathrm{~m}(100 \mathrm{ft})$ until it drops off the sheer $18-\mathrm{m}(60-\mathrm{ft})$ tuff mesa edge into the northern side of Sandia Canyon, where a plunge pool has formed.

The lower drainage initially has a thick overstory of small Gambel oak, skunkbush, and scattered ponderosa pine and is well shaded by the overstory and surrounding cliffs.

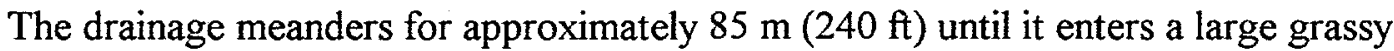
meadow to the north of East Jemez Road. This section of the channel is up to $1.2 \mathrm{~m}(4 \mathrm{ft})$ deep and $1.8 \mathrm{~m}(6 \mathrm{ft})$ wide with a substrate primarily of sand with some cobbles. The channel has cut through the loose and erodable alluvium exposing unvegetated banks. The drainage abruptly turns eastward, paralleling the north of East Jemez Road. The channel gradually spreads out, and sandy deposits mark the drainage for another $50 \mathrm{~m}(165 \mathrm{ft})$. It is apparent that past flows have seldom carried materials beyond this point. However, LEDA discharges are expected to reach the main channel of Sandia Canyon, which lies to the south of East Jemez Road.

Increased discharges will presumably flow an additional $45 \mathrm{~m}(150 \mathrm{ft})$ through the northern section of the meadow and pass under East Jemez Road through an existing culvert. Once on the south side of East Jemez Road, the effluent would enter the main

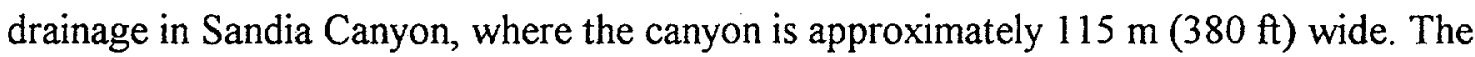
channel is $0.15-0.3 \mathrm{~m}(0.5-1.0 \mathrm{ft})$ deep and $2.5-4.6 \mathrm{~m}(8-15 \mathrm{ft})$ wide with a substrate of sands and gravels. These fine sediments and the channel's meandering pattern are characteristic of slow flows. The drainage flows along the fairly level floodplain for approximately $3.5 \mathrm{~km}$ (2.2 mi) until it passes underneath State Route 4 and briefly onto property of Bandelier National Monument. Most of lower Sandia Canyon occurs on 
Pueblo of San lldefonso lands. The canyon ultimately joins with the Rio Grande approximately $5 \mathrm{~km}(3 \mathrm{mi})$ east of LANL property.

\section{PROJECT DESCRIPTION}

\subsection{The LEDA Project}

The Department of Energy (DOE) plans to build, install, and operate a LEDA in building MPF-365 at TA-53. LEDA will demonstrate the technology of the low-energy (40 MeV or less) front end of the high-energy ( $1000 \mathrm{MeV}$ or more) accelerator that would be necessary to produce tritium. LEDA will be located at Los Alamos, but the final Accelerator Production of Tritium plant will be located at Savannah River, South Carolina.

The LEDA project is not intended to produce tritium or other radioactive materials. The proton beam will not pass through water, but neutrons produced when protons hit the beam stop may generate trace amounts of tritium when they strike the beam stop cooling water. This potentially activated water will be contained in a closed loop. This closed loop will be isolated from the cooling-tower loop by an intermediate heat-exchanger loop. The radioactive beam stop cooling loop is thus doubly-isolated from the cooling-tower loop to prevent release into the environment. The LEDA beam stop will be designed to minimize tritium production whereas the final accelerator production of tritium plant beam stop will be designed to maximize tritium production.

The purpose of LEDA is for research and development of accelerator technology only. The accelerator will be staged in five steps: 
- Stage 1 is the injector only, with a final beam energy of $0.075 \mathrm{MeV}$ and a beam current of $110 \mathrm{~mA}$.

- Stage 2 includes the injector plus a radio-frequency quadrapole (RFQ) accelerator having a final beam energy of $7 \mathrm{MeV}$ and a beam current of $100 \mathrm{~mA}$.

- Stage 3 includes the injector, RFQ, and a section of a coupled-cavity drift tube linear accelerator (CCDTL) with a final beam energy of $20 \mathrm{MeV}$ and a beam current of 100 $\mathrm{mA}$.

- Stage 4 adds another section of a CCDTL accelerator to bring the $20 \mathrm{MeV}$ beam up to $40 \mathrm{MeV}$.

- Stage 5 adds a second injector, RFQ, and 20-MeV CCDTL to bring the beam current up to $200 \mathrm{~mA}$. Another CCDTL module may be added to produce a final beam energy of $30 \mathrm{MeV}$.

The schedule (which is tentative and subject to receiving necessary funding) calls for Stage 2 to begin operation in July 1997, Stage 3 in January 1998, Stage 4 in October 1998, and Stage 5 in January 2000.

The heat generated by the LEDA bean stop will be released through water cooling towers. The cooling capacity of the present MPF-365 cooling tower is $2.9 \mathrm{MW}$, which is sufficient for Stage 1. Estimations of required cooling needed for subsequent stages are 9.5 MW for Stage 2, 16.7 MW for Stage 3, and 28.6 for both Stages 4 and 5. This will require the installation of larger cooling towers adjacent to building MPF-365 to sufficiently increase the cooling capacity. 
Increased cooling tower capacity will increase water discharge (blowdown) through Outfall 03A-113. This outfall is currently permitted, as required by the NPDES, and is monitored by LANL's ESH-18 (the Water Quality and Hydrology Group). The quantities of water to be discharged into outfall $03 \mathrm{~A}-113$ are 44,900 gal./day, 64,800 gal./day, 107,000 gal./day, and 107,000 gal./day for Stages $2-5$, respectively. These are maximized average daily discharges, calculated by dividing the projected amount of water to be discharged into the outfall each year $(17,000,000$ gal., $24,000,000$ gal., $39,000,000$ gal., and 39,000,000 gal. for Stages $2-5$, respectively) by 365 days. The first cooling water discharges will not occur until January 1997, and the project is not realistically expected to operate 365 days a year.

The new facility construction for the LEDA project would consist of a coolingtower equipment building of approximately $250 \mathrm{~m}^{2}\left(2700 \mathrm{ft}^{2}\right)$. The site for this new building was cleared and bladed for previous construction at TA-53. Building activities for the cooling tower would be contained in an area not to exceed 0.1 hectare $(0.25 \mathrm{acre})$. The existing building electrical power and cooling water utilities at Building MPF-365 are adequate for only Stage 1 of the LEDA project. Stages 2 to 5 would require upgrades of the electrical power capacities (up to $30 \mathrm{MW}$ ) and of the building cooling water systems' heat exchange capacity (up to $25 \mathrm{MW}$ ). Electrical and cooling upgrades would require some construction outside Building MPF-365. Trenches for electrical, gas, and cooling water lines would vary in length but would be about $1.5 \mathrm{~m}(5 \mathrm{ft})$ wide and $1.8 \mathrm{~m}(6 \mathrm{ft})$ deep for the $13.2 \mathrm{kV}$ duct banks (arrays of conduits or ducts for electrical wiring) and

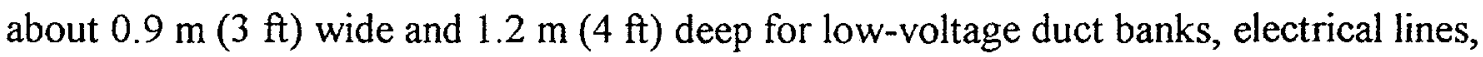


gas lines, and water lines. Erecting sheds to house cooling tower equipment, chiller units, and other equipment may require minor leveling, removal of existing equipment or utilities, pouring concrete foundations, and similar small-scale construction activities. Small amounts $\left(88 \mathrm{~m}^{3}\right.$ or $\left.3,120 \mathrm{ft}^{3}\right)$ of demolition and construction debris may be generated during internal and external construction activities. A more complete description of the project is included in the Environmental Assessment prepared for the LEDA project (ESH-20 1996).

\subsection{Annual Biological Assessments}

The USFWS reviews major federal construction projects for potential effects on threatened and endangered (T\&E) species, floodplains and wetlands, and other sensitive habitats. A Biological Assessment (Cross 1996b) was prepared for the LEDA project and submitted to the USFWS office in Albuquerque for review. It was impossible to state with certainty what effect LEDA effluent discharges would have on Sandia Canyon and whether or not a wetland area would be created. USFWS reviewers insisted that the main drainage be monitored to measure and document changes to vegetation, soils, wildlife, and habitats due to LEDA discharges. Therefore, the following section was added to the assessment to address these concerns:

“...biologists will monitor the lower drainage areas for changes in flora, fauna, and soils. We will survey permanent vegetation transects within Sandia Canyon at least annually. Pitfall traps will be installed and checked daily during the sampling season for reptiles and amphibians. Birds will be censused during the summer when resident populations and diversity are highest. Soil cores will be removed with a hand auger and examined for the presence of organic material content, streaking, and organic pans." 
The Biology Team of LANL's ESH-20 completed all aspects of the first year's monitoring program during 1996, and the results and discussion of these studies form the basis of this report. The biological monitoring area for the LEDA project is shown in Fig. 5.

The information collected prior to effluent releases will be used as baseline data to compare with subsequent data collected during active discharges and after project termination. A wetlands is defined by hydrology, vegetation, and soils; and all three of these parameters will be measured once significant effluent discharges are released into Sandia Canyon. At that time, a study of resident aquatic invertebrates will be initiated in accordance with established protocols. Water quality parameters of $\mathrm{pH}$, water temperature, dissolved oxygen, and conductivity will be measured simultaneously with invertebrate collection. These data and their analyses will be included in future annual reports.

\section{SOILS}

\subsection{Hydric Soils}

Soils, hydrology, and vegetation are the three components of a wetlands as defined by the U. S. Corps of Engineers and the U. S. Environmental Protection Agency. Soils analysis allows long-term interpretation of local conditions, as opposed to plants and hydrology, which can change relatively rapidly. Soils consist of unconsolidated natural material that supports, or is capable of supporting, plant life. The relative proportions of sand, silt, clay, and organic matter in a soil are influenced by many interacting environmental factors. Mineral soils have very little organic matter, while Histosols are composed primarily of organic matter. 
Wetlands typically have hydric soils. A hydric soil forms under conditions of saturation, flooding, or ponding sufficient to develop anaerobic conditions in the upper layers. Although all soil-forming factors (climate, parent material, relief, organisms, and time) affect the characteristics of a hydric soil, the overriding influence is the hydrological regime. The unique characteristics of hydric soils result from the influence of periodic or permanent inundation or soil saturation for sufficient duration to effect anaerobic conditions. Prolonged anaerobic soil conditions lead to a reducing environment, resulting in chemical reduction of some soil components. Such reduction ultimately leads to the development of soil colors and other physical characteristics indicative of hydric soils (WTI 1995).

Many soils in the mid-Sandia Canyon drainage are composed primarily of sand. If hydric soils develop in this area, they would be hydric mineral soils, which are composed mainly of clay, silt, and/or sand with varying amounts of organic matter. Soil color should not be used as a wetlands indicator in most sandy soils because the color of these soils is only the color of the parent material. However, three additional soil features are used as indicators of sandy hydric soils (WTI 1995):

- High organic matter content in the upper layers. Organic matter tends to accumulate in the surface layers of sandy soils that are inundated or saturated to the surface for a significant portion of the growing season. Prolonged inundation or saturation creates anaerobic conditions that greatly inhibit oxidation of organic matter and promote reducing conditions. Such reduction requires the reduction of iron rather than simply the depletion of free oxygen (Vepraskas 1995). 
- Streaking of subsurface layers by organic matter. Organic matter is moved downward through sand as the water table fluctuates. This often occurs more rapidly and to a greater degree in some vertical sections of a sandy soil containing high content of organic matter than in others. Thus, the sandy soil appears vertically streaked with darker areas.

- Organic pans. As organic matter is moved downward through sandy soils, it tends to accumulate at the point representing the most commonly occurring depth to the water table. This organic matter tends to become slightly cemented with aluminum, forming a thin layer of hardened soil. These horizontal accumulations occur at depths of 30-75 $\mathrm{cm}(12-30$ in.) below the surface.

When present, plant roots carry free oxygen into the soil. This oxygen creates reddish rhizospheres when it contacts the anaerobic soil. Such rhizospheres thus provide an additional indicator of saturated conditions, if plants occur within the sampling area.

\subsection{Soils within the LEDA Drainage}

In December 1996, the Biology Team dug soil pits down-gradient from Outfall 03A1 13, the proposed site of LEDA effluent discharges. The 3 pits dug within and beside the outfall drainage were designated with an ' $N$ ' because they occur to the north of East Jemez Road. The 3 pits dug within the main mid-Sandia Canyon were designated with an "S" because they occur to the south of the road. Each pit was $45 \mathrm{~cm}$ (18 in.) deep and steep-sided to allow accurate determination of relevant soil characteristics. Pits were placed at least $22 \mathrm{~m}(70 \mathrm{ft})$ apart. Hydric characteristics can be destroyed in a main 
channel by repeated flooding, and pits were excavated in the channel, in sand bars, and in bordering vegetation (Table 1) to sample a number of representative areas.

All soils in the excavated pits were checked for organic matter in the upper layers, streaking, organic pans, and oxidized rhizospheres (where plant roots were present). None of these hydric soil indicators were found in any of the soils. Upper layers of SH-1 soils had dark horizontal bands, but these were not the vertical streaks indicative of a hydric

Table 1. Soil Pit Locations and Soil Characteristics.

\begin{tabular}{|l|l|l|}
\hline Soil Pit \# & Location & Soil Characteristics \\
\hline NH-1 & $\begin{array}{l}\text { within lower outfall drainage at } \\
\text { sharp bend to the east, } \\
\text { unvegetated. }\end{array}$ & $\begin{array}{l}\text { surface of sand, no roots, virtually no } \\
\text { organic matter in the upper layers, upper 14 } \\
\text { cm (5.5 in.) of loose sand, lower layer a silt } \\
\text { loam. }\end{array}$ \\
\hline NH-2 & $\begin{array}{l}22 \mathrm{~m} \text { (70 ft) east of NH-1; on a } \\
\text { sand bar with scattered } \\
\text { cocklebur, false tarragon, and } \\
\text { aster. }\end{array}$ & $\begin{array}{l}\text { surface of sands and small gravels with } \\
\text { occasional cobbles, roots but no oxidized } \\
\text { rhizospheres, little organic matter near } \\
\text { surface, nearly pure sand at all depths. }\end{array}$ \\
\hline $\begin{array}{l}\text { NH-3 }(85 \mathrm{ft}) \text { east of NH-2, } \\
\text { grama and false tarragon. }\end{array}$ & $\begin{array}{l}\text { surface covered with herbaceous } \\
\text { vegetation, many roots but no oxidized } \\
\text { rhizospheres, some organic matter in the } \\
\text { upper layers, sand noticeable only in the } \\
\text { upper 4 cm (1.5 in.), some light streaking, } \\
\text { lower levels a silty clay loam. }\end{array}$ \\
\hline SH-1 & $\begin{array}{l}\text { 30 m (100 ft) east of culvert } \\
\text { under East Jemez Road, in } \\
\text { center of in,in drainage, } \\
\text { unvegetated. }\end{array}$ & $\begin{array}{l}\text { dark horizontal bands in upper 20 cm (8 in.) } \\
\text { similar to surface splotches in drainage, } \\
\text { virtually no organic matter in the upper } \\
\text { layers, nearly pure sand at all depths. }\end{array}$ \\
\hline SH-2 & $\begin{array}{l}28 \mathrm{~m}(90 \mathrm{ft}) \text { east of SH-2, north } \\
\text { of main channel but in area of } \\
\text { alluvial deposition, within area } \\
\text { vegetated with sand dropseed } \\
\text { and rabbitbrush. }\end{array}$ & $\begin{array}{l}\text { surface with plants, sand, and small gravel; } \\
\text { roots but no oxidized rhizospheres; slight } \\
\text { organic matter in the upper layers; nearly } \\
\text { pure sand at all depths. }\end{array}$ \\
\hline $\begin{array}{l}\text { 28 m (90 ft) east of SH-3; on a } \\
\text { low sand bar vegetated with } \\
\text { rabbitbrush, aster, and } \\
\text { cocklebur. }\end{array}$ & $\begin{array}{l}\text { surface with plants, sand, and small gravel; } \\
\text { roots but no oxidized rhizospheres; slight } \\
\text { organic matter in the upper layers; nearly } \\
\text { pure sand at all depths. }\end{array}$ \\
\hline
\end{tabular}


soil. (Much of the surface of the mid-Sandia Canyon drainage had similar deposits, which are believed to be accumulations of silts and clays from recent flooding.) Apparently, the periods of saturation in the lower Outfall 03A113 and mid-Sandia Canyon drainages are too short to produce hydric soils.

\section{WATER QUALITY}

\subsection{Sandia Canyon and Water Quality Standards}

ESH-18 installed a water-gaging station in mid-Sandia Canyon near the eastern LANL boundary. The drainage area above the station is $6.53 \mathrm{~km}^{2}\left(2.52 \mathrm{mi}^{2}\right)$, and the flow is partially regulated by the Los Alamos Reservoir in nearby Los Alamos Canyon. This station is equipped with a data logger with cellular telemetry and concrete control. From October 1994 through September 1995, flow was only recorded on 5 dates, with a total flow of $2.51 \mathrm{ft}^{3} / \mathrm{sec}$ (Shaull et al. 1996).

The State of New Mexico establishes water standards to sustain and protect existing or attainable uses of water in the State. The most recent State of New Mexico Standards for Interstate and Intrastate Streams (State of New Mexico 1995) published by the Water Quality Control Commission states, "These general standards apply at all times, unless a specified standard is provided elsewhere in this document, to all surface waters of the State."

The specific standards that apply to waters originating within and/or flowing through LANL property have not yet been fully resolved. The standards of "wildlife habitat" and "livestock watering" apply unless it can be demonstrated that these uses are not appropriate. The appropriateness of other uses, such as "fishery use," is currently under study. At present, the designated use of LANL streams segments, including Sandia 
Canyon, is "wildlife habitat." Once LEDA discharges release sufficient water to allow sampling, the Biology Team will monitor physical-chemical parameters of conductivity, water temperature, dissolved oxygen, and $\mathrm{pH}$ in mid-Sandia Canyon to document compliance with the criteria for wildlife habitat. These measurements will be taken concurrently with aquatic invertebrate collection.

\subsection{NPDES Sampling}

A water quality team from ESH-18 samples Outfall $03 \mathrm{~A} 113$ quarterly as required by NPDES regulations. Measurements of $\mathrm{pH}$, total suspended solids, chlorine, phosporus, and aresenic were taken at the outfall's point of discharge in February, May, August, and November of 1996. NPDES regulations require that Outfall 03A113 effluent pH be kept within 6-9 standard units and that other monitored constituents not exceed predetermined daily average and daily maximum values (Table 2). None of the monitored components exceeded the NPDES maximum allowable limits during 1996.

Table 2. NPDES Limits for Outfall 03A113.

\begin{tabular}{|l|c|c|}
\hline \multicolumn{1}{|c|}{ Effluent Constituent } & $\begin{array}{c}\text { Maximum Allowable } \\
\text { Daily Average (mg/) }\end{array}$ & $\begin{array}{c}\text { Allowable Daily } \\
\text { Maximum }\end{array}$ \\
\hline Total suspended solids & 30 & 100 \\
\hline Phosphorus & 20 & 40 \\
\hline Arsenic & 0.04 & 0.04 \\
\hline Chlorine & 0.2 & 0.5 \\
\hline
\end{tabular}

\section{VEGETATION}

\subsection{Vegetation of LANL}

Located in a semiarid environment, New Mexico is characterized by plant communities ranging from Chihuahuan desertscrub to alpine tundra (Brown 1980). Northcentral New Mexico contains a variety of vegetative complexes that are directly influenced 
by the wide range of elevational zones. Upland (nonriparian) mountainous areas contain two climatic zones consisting of three plant communities: the Rocky Mountain Subalpine Conifer Forest and Woodland, the Rocky Mountain Montane Conifer Forest, and the Great Basin Conifer Woodland (Brown 1980). Lower elevations encompass two grassland climatic zones, which contain at least three different upland communities: the Plains Grassland, the Great Basin Shrub Grassland, and the Rocky Mountain Montane Grassland.

In addition to the upland communities, numerous wetland (riparian) plant communities occur in association with most of the previously mentioned uplands. Due to the large number of wetland communities, a more general description of the climatic zones in which these communities are located, is given. These wetland communities are located within five different climatic zones and include the Cold Temperate Swamp and Riparian Forest, the Arctic-Boreal Swamp-Scrub, the Arctic-Boreal Marshland, the Arctic-Boreal Strand (streams, lakes), and the Cold Temperate Strand (streams, lakes).

The Rio Grande floodplain contains the lowest elevations in or near Los Alamos County and is characterized by a Plains and Great Basin Riparian-Deciduous Forest with cottonwood (Populus spp.) and willow (Salix spp.) within its boundaries. Salt cedar (Tamarix pentandra) and Russian olive (Elaeagnus angustifolia), both introduced species, are also present. Juniper and piñon pine are the typical upland overstory species at elevations ranging from about $1,705-1,890 \mathrm{~m}(5,600-6,200 \mathrm{ft})$. Both of these species are typical of the Great Basin Conifer Woodland; and both are also common at higher elevations $(1,890-2,105 \mathrm{~m}$ or $6,200-6900 \mathrm{ft})$ where they occupy large areas on the mesa tops. In the western portion of Los Alamos County, the woodland community intergrades 
with species of the Rocky Mountain Montane Conifer Forest. Ponderosa pine is a common species at about $2,105-2,285 \mathrm{~m}(6,900-7,500 \mathrm{ft})$ on the higher mesa tops and along many of the north-facing canyon slopes. White fir also occurs along the higher north-facing slopes intermixing with ponderosa pine in a mixed-conifer community. Species of the Rocky Mountain Subalpine Conifer Forest and Woodland occur along the extreme western edge of the county and are more prevalent at the higher elevations of the nearby Jemez Mountains.

Most of the streams within Los Alamos County are ephemeral (flowing during precipitation and runoff events). However, permanent flow from springs and LANL, facility discharges create a small number of perennial or near-perennial stream flows within short stretches of certain canyons. Many of these streams and other wetlands are characterized by vegetation of the Rocky Mountain Riparian Deciduous Forest and the Plains Interior Marshland.

\subsection{Vegetation of the Project Area}

The Biology Team conducted vegetation surveys within meadows in the lower outfall drainage area and in mid-Sandia Canyon, where LEDA discharges may ultimately flow. We surveyed these areas in September 1996 to establish baseline conditions prior to the release of LEDA effluent discharges. Plants were identified with the aid of standard reference books, including Martin and Hutchins (1980), Allred (1993), Ivey (1995), Hitchcock and Chase (1971), and Foxx and Hoard (1995). When necessary, voucher specimens were collected and archived in the ESH-20 herbarium. Questionable identifications were confirmed at the University of New Mexico herbarium. All four 
surveyed transects were staked as permanent sampling plots to be reused in subsequent vegetational surveys.

Only understory transects were conducted due to the lack of overstory in the meadows. The Biology Team placed the transects perpendicular to the drainage in lowgradient areas where water might tend to pool in the future. A transect line length of $46 \mathrm{~m}$ $(150 \mathrm{ft})$ was chosen because that distance nearly spans the width of the meadow at transects 1 and 2. Percent cover of cryptogamic and herbaceous plants, bare soil, rock, and litter were measured with $20-\times 50-\mathrm{cm}(7.9-\times 19.7-\mathrm{in}$. $)$ plots, which were established every $3 \mathrm{~m}(10 \mathrm{ft})$ along the transect line (Daubenmire 1959).

The vegetation data was analyzed by cover, relative plant cover, frequency, and relative frequency. An importance index was calculated for each plant species in each transect by averaging its relative plant cover and relative frequency. The importance index is a valid measure of species dominance within the area. All species recorded during the 1996 vegetation surveys are listed in Appendix A.

Transects 1 and 2 occur in a low meadow to the north of East Jemez Road. The soil appears to have been scraped off many years ago, possibly for road construction. Two large ponderosa pines grow in a relatively undisturbed setting, and the understory plant community between them are more characteristic of natural areas. A few scattered shrub thickets of chamisa (Chrysothamnus nauseosus) and wax currant (Ribes cereum) also occur in the meadow. Table 3 lists the primary understory species (any having any importance index greater than or equal to 5.00) found within transects 1 and 2 .

Transect 1 had a total plant cover of $29.65 \%$, primarily because of the many unvegetated areas due to deposition of loose materials. A 2.4-m (8- $\mathrm{ft}$ ) -wide swathe of 
Table 3. Dominant Understory Plants in the LEDA Drainage, Transects 1 and 2.

\begin{tabular}{|c|c|c|c|c|}
\hline Transect & $\begin{array}{l}\text { Scientific name } \\
\text { (Common name) }\end{array}$ & $\begin{array}{c}\text { Relative } \\
\text { plant cover }\end{array}$ & $\begin{array}{r}\text { Relative } \\
\text { frequency }\end{array}$ & $\begin{array}{c}\text { Importance } \\
\text { Index }\end{array}$ \\
\hline 1 & $\begin{array}{l}\text { Bouteloua gracilis } \\
\text { (blue grama) }\end{array}$ & 25.30 & 12.96 & 19.13 \\
\hline 1 & $\begin{array}{l}\text { Bromus inermis } \\
\text { (smooth brome) }\end{array}$ & 17.71 & 11.11 & 14.41 \\
\hline 1 & $\begin{array}{l}\text { Artemisia dracunculus } \\
\text { (false tarragon) }\end{array}$ & 8.43 & 11.11 & 9.77 \\
\hline 1 & $\begin{array}{l}\text { Bromus frondosus } \\
\text { (weeping brome) }\end{array}$ & 11.80 & 3.70 & 7.75 \\
\hline 1 & $\begin{array}{l}\text { Verbascum thapsus } \\
\text { (mullein) }\end{array}$ & 6.75 & 7.41 & 7.08 \\
\hline 1 & $\begin{array}{l}\text { Elymus trachycaulus } \\
\text { (slender wheatgrass) }\end{array}$ & 4.22 & 7.41 & 5.81 \\
\hline 1 & $\begin{array}{l}\text { Xanthium strumarium } \\
\text { (cocklebur) }\end{array}$ & 3.37 & 7.41 & 5.39 \\
\hline 1 & $\begin{array}{l}\text { Erograstis mexicana } \\
\text { (Mexican lovegrass) }\end{array}$ & 6.75 & 3.70 & 5.22 \\
\hline 2 & $\begin{array}{l}\text { Bouteloua gracilis } \\
\text { (blue grama) }\end{array}$ & 25.23 & 21.05 & 23.14 \\
\hline 2 & $\begin{array}{l}\text { Artemisia dracunculus } \\
\text { (false tarragon) }\end{array}$ & 24.08 & 18.42 & 21.25 \\
\hline 2 & $\begin{array}{l}\text { Verbascum thapsus } \\
\text { (mullein) }\end{array}$ & 6.88 & 10.53 & 8.70 \\
\hline 2 & $\begin{array}{l}\text { Erograstis mexicana } \\
\text { (Mexican lovegrass) }\end{array}$ & 6.88 & 10.53 & 8.70 \\
\hline 2 & $\begin{array}{l}\text { Sporobolus cryptandrus } \\
\text { (sand dropseed) }\end{array}$ & 12.61 & 5.26 & 8.04 \\
\hline 2 & $\begin{array}{l}\text { Viguiera multiflora } \\
\text { (goldeneye) }\end{array}$ & 2.52 & 7.89 & 5.21 \\
\hline
\end{tabular}

alluvial sediments marked the drainage in this transect, although eroded sediments were noted alongside the drainage for an additional $4.3 \mathrm{~m}(14 \mathrm{ft})$. A total of 18 species of plants was recorded within the transect, including 7 grasses.

Transect 2 had a total plant cover of $21.80 \%$. The drainage had no defined channel, but loose sediments deposited by flowing water were noted for a distance of $10 \mathrm{~m}$ (34 ft) across the transect line. Transect 2 contained 13 plant species, including 6 grasses. 
Transects 3 and 4 are south of East Jemez Road and downstream from the midSandia Canyon culvert. The canyon is narrow with a fairly thick growth of ponderosa pines until approximately $30 \mathrm{~m}(100 \mathrm{ft})$ upstream from the culvert, where it flattens and the trees thin out. In this section, the drainage forms a braided system with many meandering and shifting channels that are usually dry. On the south side of the road, the meadow widens to $70 \mathrm{~m}(230 \mathrm{ft})$ and supports only scattered ponderosa pines, rabbitbrush (Chrysothammus nauseosus), wax currant, and New Mexico locust (Robinia neomexicana). Table 4 lists the primary understory species (any having an importance index greater than or equal to 5.00) found within transects 3 and 4.

Transect 3 had a total plant cover of only $11.6 \%$, due to the extensive sand deposits carried downstream by flowing water from upper-Sandia Canyon. The main Table 4. Dominant Understory Plants in the LEDA Drainage, Transects 3 and 4.

\begin{tabular}{|c|c|c|c|c|}
\hline Transect & $\begin{array}{c}\text { Scientific name } \\
\text { (Common name) }\end{array}$ & $\begin{array}{c}\text { Relative } \\
\text { plant cover }\end{array}$ & $\begin{array}{c}\text { Relative } \\
\text { frequency }\end{array}$ & $\begin{array}{c}\text { Importance } \\
\text { Index }\end{array}$ \\
\hline 3 & $\begin{array}{l}\text { Artemisia dracunculus } \\
\text { (false tarragon) }\end{array}$ & 34.58 & 10.34 & 22.46 \\
\hline 3 & $\begin{array}{l}\text { Artemisia carruthii } \\
\text { (wormwood) }\end{array}$ & 23.05 & 13.79 & 18.42 \\
\hline 3 & $\begin{array}{l}\text { Sporobolus cryptandrus } \\
\text { (sand dropseed) }\end{array}$ & 10.09 & 13.75 & 11.94 \\
\hline 3 & $\begin{array}{l}\text { Erograstis mexicana } \\
\text { (Mexican lovegrass) }\end{array}$ & 5.76 & 10.74 & 8.05 \\
\hline 3 & $\begin{array}{l}\text { Chenopodium album } \\
\text { (lamb's quarters) }\end{array}$ & 4.32 & 6.90 & 5.61 \\
\hline 4 & $\begin{array}{l}\text { Artemisis dracunculus } \\
\text { (false tarragon) }\end{array}$ & 44.12 & 25.00 & 34.56 \\
\hline 4 & $\begin{array}{l}\text { Sporobolus cryptandrus } \\
\text { (sand dropseed) }\end{array}$ & 11.34 & 16.67 & 34.56 \\
\hline 4 & $\begin{array}{l}\text { Bouteloua gracilis } \\
\text { (blue grama) }\end{array}$ & 8.40 & 8.33 & 8.37 \\
\hline 4 & $\begin{array}{l}\text { Portulaca oleracea } \\
\text { (common purslane) }\end{array}$ & 12.61 & 4.17 & 8.39 \\
\hline
\end{tabular}


drainage occupied $9 \mathrm{~m}(30 \mathrm{ft})$ of the transect, but side drainage and sediment deposits extended for an additional $13 \mathrm{~m}(42 \mathrm{ft})$. The Biology Team recorded 17 plant species within transect 3 , including 5 grasses.

Transect 4 had a total plant cover of only $11.90 \%$, due to sand deposits from the upper canyon. The main drainage cut across $10.5 \mathrm{~m}(34.5 \mathrm{ft})$ of the transect, and other deposits undoubtedly limited plant growth. Transect 4 contained 15 plant species, including 5 grasses.

A total of 29 plant species, including 9 grasses, were found in the 4 vegetation transects. All of these plants are upland species, which indicates the ephemeral nature of flows within mid-Sandia Canyon. Plant cover averaged only $18.73 \%$ due to extensive deposits of sand and other erodible materials carried from upstream areas. The average cover value of transects 1 and $2(25.72 \%)$ was higher than that of transects 3 and 4 $(11.75 \%)$ because their side-canyon has received significantly less erosional materials. In terms of relative cover and relative frequency, the most abundant plant species in the ransects were herbaceous sagebrushes (Artemisia spp.), sand dropseed (Sporobolus cryptandrus), and blue grama (Bouteloua gracilis). These three taxa account for $61.1 \%$ of the combined importance indices for all transects. These plants are frequently associated with disturbed areas, and their dominance indicates a high level of previous disturbance in mid-Sandia Canyon. The area has never recovered from past scraping for the construction of East Jemez Road. Seasonal flooding in the canyon also contributes to soil instability. 


\section{WLDLIFE}

\subsection{Wildlife of LANL}

The wide range of plant communities contain a correspondingly wide range of micro- and macro-habitats in the Los Alamos County area. This diversity of habitats results in a relatively wide diversity of wildlife species, including both invertebrates and vertebrates.

6.1.1 Invertebrates. Surveys for terrestrial and aquatic invertebrates have been conducted on the Laboratory and Bandelier National Monument. However, the results from these surveys are restricted to localized areas and are limited in regional application. Members of the Biology Team have found 4 genera of aquatic mollusks and 15 genera of terrestrial mollusks on LANL property. Researchers have found 193 genera of aquatic insects and 20 other aquatic non-insects taxa in the waterways on and adjacent to LANL property. At least 89 families of terrestrial insects and 45 families of terrestrial non-insect arthropods have been identified on the Laboratory property.

6.1.2 Fish. Due to the primarily ephemeral nature of the waterways, no fish have been found on Laboratory property. Fish have been observed in nearby Guaje Canyon, Los Alamos Canyon, and at the confluence of White Rock Canyon and the Rio Grande. A current USFWS study will determine if fish can survive within LANL canyons, including Cañon de Valle and upper Pajarito Canyon.

6.1.3 Reptiles and Amphibians. A variety of reptiles are common throughout much of the County and include at least 14 species of skinks, lizards, and snakes. The presence of wetlands adds additional habitat for water-associated species. At least seven species of amphibians are found in the County. 
6.1.4 Birds. Birds are the most diverse group of wildlife found in the area, which is in part, due to the wide range of habitats. This group includes a variety of nesting and migrating raptors that occupy some of the relatively undisturbed areas and the steeper canyon walls. Over 200 bird species have been recorded in Los Alamos County, including at least 112 species of breeding birds (Travis 1992), most of them migratory summer residents.

6.1.5 Mammals. At least 29 species of small mammals occur in the area, some of which are specific to particular elevational ranges. Deer mice (Peromyscus maniculatus), woodrats (Neotoma mexicana), and least chipmunks (Eutamias minimus) inhabitat most areas of the region. Piñon mice (Peromyscus trueii) are found primarily in pinyon-juniper woodlands; the western red-backed vole (Clethrionomys californicus) occurs in the higher elevations; and the western harvest mouse (Reithrodontomys megalotis) and long-tailed voles (Microtus longicaudus) are found in moist canyon bottoms. Shrews (Sorex palustrus and $S$. vagrans)are found near flowing water. Thirteen species of bats (order Chiroptera) have been recorded within LANL boundaries.

The most commonly seen large mammals n Los Alamos County are mule deer (Odocoileus hemionus) and elk (Cervis elaphus nelsonii). These species generally winter in the lower elevations of the Pajarito Plateau, including mesas and canyons along the central and eastern portions of the County and surrounding areas, and spend their summers at the higher elevations of the Jemez Mountains. However, recent surveys in the Los Alamos County area indicate growing populations of these species residing yearround at lower elevations. Little population data is available for the other large- and 
medium-size mammals of the area, but also present are at least 12 species of carnivores, including mountain lion (Felix concolor), bobcat (Lynx rufus), fox (Vulpes fulva), and coyote (Canis latrans).

\subsection{Wildlife of the Project Area}

The Biology Team selected several groups of animals to monitor the effects of LEDA discharges on local wildlife. The 1996 studies were conducted to provide baseline data documenting conditions in mid-Sandia Canyon prior to LEDA releases. An increase in available drinking water is expected to increase bird diversity and abundance, and the Biology Team conducted a bird survey in the canyon during August 1996. We monitored reptile and amphibian populations daily for a 2-month period in the late summer of 1996. These studies will continue during the life of the project and may be supplemented by the monitoring of large mammal movements within the canyon. Once LEDA begins to discharge significant quantities of effluent, the Biology Team will initiate aquatic invertebrate studies within areas of standing and/or flowing water.

6.2.1 Birds. David Keller, an experienced ornithologist on the Biologist Team, systematically walked mid-Sandia Canyon to determine its resident summer bird populations. The survey includes 15 observation points with approximately 200 meters between adjacent points. The survey begins soon after daybreak and ends before $11 \mathrm{AM}$, usually the best time for recording the maximum numbers of bird species and individuals. Observations consists of 6 minutes spent at each point, during which all species heard and/or seen are recorded. Each observation includes the individual's species, sex, age, and estimated distance from the observation point. Habitat type and meteorological 
information are also recorded at all observation points, which are marked for subsequent surveys. Unknown birds are identified with a published guide in the field (National Geographic Society 1987) or on return to the lab (Ehrlich et al. 1988 and Travis 1992).

David Keller conducted a bird survey within the future LEDA drainage in midSandia Canyon on 14 August 1996. He found a total of 109 individuals of 25 bird species (Appendix B), the most common being American robins (Turdus migratorius), chipping sparrows (Spizella passerina), mountain chickadees (Parus gambeli), and pygmy nuthatches (Sitta pygmaea). These results are typical of local dry canyons that are disturbed by frequent road noise.

6.2.2 Reptiles and Amphibians. Reptiles and amphibians are captured in pitfall traps, containers dug into the ground so that the top is flush with the ground surface (Heyer 1994). Animals stumble into the traps and cannot climb out the vertical sides. Drift fences are metallic obstructions placed to intercept the animals and to direct them towards the pitfall traps. A pitfall array consists of 4 traps placed along a drift fence, one trap on each side at each end of the fence. The Biology Team constructed eight pitfall arrays in midSandia Canyon, 4 along each side of East Jemez Road. Each array consisted of 4 1-gallon buckets and a 30-cm (12 in.)-high and 5-m (16 ft)-long drift fence. Arrays were placed within and near to the future LEDA drainage and spaced at least $20 \mathrm{~m}(65 \mathrm{ft})$ apart.

In the Biology Team laboratory, species name, mass, total length, tail length, and tail regrowth rate (where applicable) were recorded for all captured amphibians and reptiles. A Mitutoyo Scale measured snout-vent length and vent-tail tip length, and a Mettler Scale measured the animal's mass. Larger individuals were implanted with a 
passive integrated transponder (PIT) for recapture identification (Camper and Dixon 1988; Schooley and Van Horne unpublished). PIT tags are small capsules containing microchips that are injected into the abdominal cavity. Tags are activated by a portable reader and are a relatively harmless method of mark-recapture. All captured individuals were returned to their place of capture within 24 hours of capture.

Pitfall traps were opened on Monday, checked Tuesday through Friday, and closed on Friday. The trapping season in mid-Sandia Canyon ran from 26 July-30 September 1996. During that period, 32 individuals of 4 species were captured (Appendix C). Only 1 amphibian, a tiger salamander (Ambrystoma tigrinum) captured on 19 September, was caught. LEDA discharges are expected to increase the numbers and relative abundances of amphibians, including tiger salamanders, chorus frogs (Pseudacris triseriata), Woodhouse toads (Bufo woodhousei), and western spade-foot toads (Scaphiopus hammondii) within mid-Sandia Canyon.

6.2.3 Large Mammals. In 1948, the New Mexico Game and Fish Department released 28 Rocky Mountain elk into the Jemez Mountains. This initial population has dramatically increased to an estimated $6,000-8,000$ head (Gonzales et al. 1995). Many elk remain on LANL property throughout the year, and elk calves have been observed in Sandia Canyon, Cañada del Buey, and Pajarito Canyon. Increases in both elk and mule deer are thought to result from a lack of hunting pressure and the expansion of suitable foraging habitat following the $1977 \mathrm{La}$ Mesa Fire.

Between January 1990 and February 1995, police reports documented 105 accidents in Los Alamos County due to vehicular collisions with mule deer (54) and elk 
(51) (Gonzales et al. 1995). During that period, the section of East Jemez Road from State Route 4 to Diamond Drive has experienced 3 elk, 1 deer, and 1 coyote vehicular collisions. Throughout the County, the greatest numbers of these collisions occurred during fall and from 4:00 PM-12:00 AM.

Increased water in mid-Sandia Canyon from LEDA discharges should increase habitat attractiveness to both deer and elk. If substantial numbers of large mammals move into the area, it may be necessary to post warning signs, decrease the speed limit, or fence off the area along East Jemez Road. The Biology Team will monitor large animal movements within this area if the necessary funding becomes available.

\section{THREATENED AND ENDANGERED SPECIES}

The USFWS lists seven T\&E animals and no T\&E plants as occurring in or potentially occurring in Los Alamos County. The potential occurrences are based on preferred habitats of the species and the presence of those habitats are found within or near Los Alamos County. Table 5 lists all T\&E plant and wildlife species occurring or potentially occurring in the County along with their listing status and preferred habitat. In addition to these officially listed species, twelve other species of concern occur or potentially occur in Los Alamos County. These species are monitored by the USFWS and may be listed in the future.

The primary impact of the LEDA project on the surrounding environment could be habitat improvement due to the addition of noncontaminated water to a typically dry section of Sandia Canyon. This may make the area more attractive to the following species: 
Table 5. USFWS T\&E Species List for Los Alamos County.

\begin{tabular}{|c|c|c|c|c|}
\hline Common Name & & Scientific Name & Status* & Habitat Description \\
\hline Black-footed ferret & & Mustela nigripes & $E$ & $\begin{array}{l}\text { Prairies, usually in prairie } \\
\text { dog towns. }\end{array}$ \\
\hline $\begin{array}{l}\text { American peregrine } \\
\text { falcon }\end{array}$ & & $\begin{array}{l}\text { Falco peregrinus } \\
\text { anatum }\end{array}$ & $E$ & $\begin{array}{l}\text { Ponderosa and piñon; } \\
\text { nests in cliffs and rock } \\
\text { outcrops on cliffs, known } \\
\text { to breed locally. }\end{array}$ \\
\hline Arctic peregrine falco & & $\begin{array}{l}\text { Falco peregrimus } \\
\text { tundrius }\end{array}$ & $\mathrm{T}(\mathrm{S} / \mathrm{A})$ & $\begin{array}{l}\text { Nests in Alaska and } \\
\text { northern Canada, migrates } \\
\text { along coasts to southern } \\
\text { U.S. and Mexico. }\end{array}$ \\
\hline Bald eagle & & $\begin{array}{l}\text { Haliaeetus } \\
\text { leucocephalus }\end{array}$ & $\mathrm{T}$ & $\begin{array}{l}\text { Riparian areas, wetlands, } \\
\text { and open water for } \\
\text { wintering and migrating } \\
\text { eagles. }\end{array}$ \\
\hline Mexican spotted owl & & $\begin{array}{l}\text { Strix occidentalis } \\
\text { lucida }\end{array}$ & $\mathrm{Tw} / \mathrm{CH}$ & $\begin{array}{l}\text { Mixed conifer in uneven- } \\
\text { aged and multi-storied } \\
\text { forests with closed } \\
\text { canopies, mountains and } \\
\text { canyons; known to breed } \\
\text { locally. }\end{array}$ \\
\hline $\begin{array}{l}\text { Southwestern willow } \\
\text { flycatcher }\end{array}$ & & $\begin{array}{l}\text { Empidonax traillii } \\
\text { extimus }\end{array}$ & $\begin{array}{l}\mathrm{E} \\
w / \mathrm{PCH}\end{array}$ & $\begin{array}{l}\text { Nesting habitat includes } \\
\text { shrubs and trees in willow } \\
\text { thickets, shrubby mountain } \\
\text { meadows, and deciduous } \\
\text { woodlands along streams, } \\
\text { lakes, and bogs. }\end{array}$ \\
\hline Whooping crane & & Grus americana & $E$ & $\begin{array}{l}\text { Nests in Canada, winters } \\
\text { along Rio Grande where it } \\
\text { roosts near water. }\end{array}$ \\
\hline \multicolumn{5}{|l|}{ * Status Index } \\
\hline $\mathrm{E}$ & $=$ & \multicolumn{3}{|l|}{ Endangered } \\
\hline $\mathrm{PE}$ & $=$ & \multicolumn{3}{|c|}{ Proposed endangered } \\
\hline $\mathrm{T}$ & $=$ & \multicolumn{3}{|l|}{ Threatened } \\
\hline $\mathrm{PCH}$ & $=$ & \multicolumn{3}{|c|}{ Proposed critical habitat } \\
\hline $\mathrm{PT}$ & $=$ & \multicolumn{3}{|l|}{ Proposed threatened } \\
\hline $\mathrm{PT} w / \mathrm{CH}$ & $=$ & \multicolumn{3}{|c|}{ Proposed Threatened with critical habitat } \\
\hline S/A & $=$ & \multicolumn{3}{|c|}{ Similarity of appearance } \\
\hline
\end{tabular}


peregrine falcon (Falco peregrimus) - raptor, endangered species, ferruginous hawk (Buteo regalis) - raptor, species of concern, loggerhead shrike (Lanius ludoviciamus) - raptor, species of concern, northern goshawk (Accipiter gentilis) - raptor, species of concern, spotted bat (Euderma maculatum) - bat, species of concern, big free-tailed bat (Nyctinomops macrotis) - bat, species of concern, long-legged myotis (Myotis volans) - bat, species of concern, and occult little brown bat (Myotis lucifugus occultus) - bat, species of concern.

Increased water may increase the number of vertebrate prey for the raptors and invertebrate prey for the bats. The tall tuff cliffs provide good raptor foraging habitat, and spotted bats may start to roost in the cliffs if water pools within the canyon. Construction activities would be confined to previously disturbed areas, which are unsuitable habitat for animal species that potentially inhabit the larger surrounding area. Therefore, it has been determined that the LEDA project may beneficially affect, but is not likely to adversely affect, potential foraging habitat for the raptors and bats listed above.

\section{BIOLOGICAL BEST MANAGEMENT PRACTICES}

The Biology Team will continue to collect baseline data from mid-Sandia Canyon to establish pre-project conditions. Water quality testing and aquatic invertebrate sampling will be initiated as soon as the project begins to discharge significant amounts of water.

Best managment practices (bmps) addressing potential biological concerns will be written throughout the life of the project. At present, several biological bmps deserve mention:

Heavy equipment must not be used within the stream channel or floodplain. Offroad traffic is not permitted within the stream channel or floodplain without prior approval by the Biology Team. 
All recommendations contained within the Storm Water Pollution Prevention Plan developed for the area must be closely followed.

Care must be taken to minimize erosion of upper areas. It may be necessary to install concrete or gabions to limit deep cutting in the plunge pool at the cliff base.

If significant numbers of large mammals move into the area because of increased drinking water, it may be necessary to install fencing along sections of East Jemez Road to exclude the animals from the roadway.

Once LEDA discharges have ceased, it may be necessary to revegetate the lower area with an appropriate seed mix to restore vegetation.

\section{CONCLUSIONS}

This first annual biological evaluation of the area affected by the LEDA project area seeks to establish biological baselines prior to the release of effluent discharges. Such monitoring before, during, and after project completion was necessary to secure USFWS concurrence with the environmental and biological assessments prepared for the proposed project. The report discusses the biota and physical characteristics of the drainage in midSandia Canyon that will eventually receive the effluent discharges. A section on biological best management practices is also included.

NPDES water quality monitoring at Outfall $03 \mathrm{Al} 13$ found no exceedances of $\mathrm{pH}$, chlorine, phosphorus, total suspended solids, or arsenic during 1996. The soils in the lower outfall drainage and the main drainage in mid-Sandia Canyon are primarily composed of sand. These soils do not contain charcteristics of hydric soils, such as high organic matter content in the upper layers, vertical streaking, organic pans, or oxidized 
rhizospheres. Apparently, the periods of saturation in the lower Outfall 03A113 and midSandia Canyon drainages are of too short a duration to produce hydric soils.

A total of 29 plant species, including 9 grasses, were found in the 4 vegetation transects. All of these plants are upland species, which indicates the ephemeral nature of flows within mid-Sandia Canyon. Plant cover averaged only $18.73 \%$ due to extensive deposits of sand and other erodible materials carried from upstream areas. The most abundant plant species in the transects were herbaceous sagebrushes, sand dropseed, and blue grama, and these three taxa account for $61.1 \%$ of the combined importance indices for all transects. These plants are frequently associated with disturbed areas, and their dominance indicates a high level of previous disturbance in mid-Sandia Canyon. The area has never recovered from past scraping for the construction of East Jemez Road. Seasonal flooding in the canyon also contributes to soil instability.

A bird survey within the future LEDA drainage in mid-Sandia Canyon found a total of 109 individuals of 25 bird species, the most common being American robins, chipping sparrows, mountain chickadees, and pygmy nuthatches. These results are typical of local dry canyons that are disturbed by frequent road noise.

Pitfall traps captured 32 individuals of 4 reptile and amphibian species. Only 1 amphibian, a tiger salamander, was caught. LEDA discharges are expected to increase the numbers and relative abundances of amphibians (such as tiger salamanders, chorus frogs, Woodhouse toads, and spade-foot toads) within mid-Sandia Canyon.

Between January 1990 and February 1995, police reports documented 105 accidents in Los Alamos County due to vehicular collisions with mule deer (54) and elk 
(51). Increased water in mid-Sandia Canyon from LEDA discharges should increase habitat attractiveness to both deer and elk. If substantial numbers of large mammals move into the area, it may be necessary to post warning signs, decrease the speed limit, or fence off the area along East Jemez Road. The Biology Team will monitor large animal movements within this area if the necessary funding becomes available.

In terms of T\&E species, the primary impact of the LEDA project on the surrounding environment may be habitat improvement due to the addition of noncontaminated water to a typically dry section of Sandia Canyon. This may make the area more attractive to a federally protected raptor and several species of concern. Therefore, it has been determined that the LEDA project may beneficially affect, but is not likely to adversely affect, potential foraging habitat for these species.

\section{ACKNOWLEDGMENTS}

The author wishes to thank several people for their efforts and contributions on behalf of this project. Vernon Smith of AOD-2 consistently supported the biological work required for USFWS review and the subsequent annual assessments. David Keller oversaw the reptile and amphibian project, performed the bird survey and analyzed its data, and assisted with the vegetation surveys. Hector Hinojosa edited the manuscript and offered valuable suggestions on its handling. The entire Biology Team provided support by reviewing and editing the manuscript, generating maps, and assisting with other tasks that allowed this report to be completed on time. 


\section{GLOSSARY OF ACRONYMS AND TECHNICAL TERMS}

anaerobic - lacking free oxygen.

asl - above sea level.

Biology Team - a LANL team within ESH-20 charged with monitoring the environment.

blowdown - water discharged from cooling towers.

bmp - best managment practice.

CCDTL - coupled-cavity drift tube linear accelerator.

DOE - Department of Energy.

effluent - the outflow of a cooling tower, sanitary line, or other source of discharge.

EPG - Environmental Protection Group.

ESH-18 - LANL's Water Quality and Hydrology Group; a group within the Laboratory's Environment, Safety, and Health Division.

ESH-20 - LANL's Ecology Group; a group within the Laboratory's Environment, Safety, and Health Division.

forb - a non-woody plant that is not a grass or grasslike. 
gabion - a wire basket filled with rocks and placed to prevent erosional losses.

gpm - gallons per minute.

hydric - of a wet or moist environment.

importance index - a measure of a plant species dominance in a community.

Laboratory - Los Alamos National Laboratory.

LANL - Los Alamos National Laboratory.

LEDA - Low Energy Demonstration Accelerator.

$\mathrm{mA}$ - milliampere.

macroinvertebrate - an invertebrate large enough to be seen without magnification.

MW - megawatt.

NPDES - National Pollutant Discharge Elimination System.

NWI - National Wetlands Inventory.

overstory - the upper vegetation of an area, consisting of trees.

PIT - passive integrated transponder.

quadrat - a rectangular border used to define a particular area to be surveyed. 
raptor - a predatory bird.

RFQ - radio-frequency quadrapole.

rhizosphere - an area surrounding a plant root, which becomes reddish in an anaerobic environment.

substrate - the surface materials on a streambed or floodplain.

SWCS - Solid Waste Consolidation System.

TA - Technical Area.

$T \& E$ - threatened and endangered.

transect - a defined survey line.

tuff - rock composed of compacted volcanic ash.

understory - the lower vegetation of an area, consisting of grasses, forbs, and small shrubs.

USFWS - U.S. Fish and Wildlife Service. 


\section{CITATIONS}

Allred, K. W., A Field Guide to the Grasses of New Mexico, New Mexico State University, Las Cruces, New Mexico (1993).

Bennett, K., "Aquatic Macroinvertebrates and Water Quality Monitoring of Sandia Canyon," LANL report LA-12738 (1994).

Brown, D. E., "Biotic Communities of the American Southwest-United States and Mexico" in Desert Plants, Volume 4, Numbers 1-4, University of Arizona, Tucson, Arizona (1980).

Camper, J. D., J. R. Dixon, "Evaluation of a Microchip Marking System for Amphibians and Reptiles," Texas Parks and Wildlife Dept., Res. Publication 7100-159:1-22 (1988).

Cowardin, L. M., V. Carter, F. C. Glet, and E. T. LaRoe, Classification of Wetlands and Deep Water Habitats of the United States, U. S. Fish and Wildlife Service, Washington, D.C., Publication No. FWS/OBS-79/31 (1979).

Cross, S., "Aquatic Macroinvertebrates and Water Quality of Sandia Canyon, Los Alamos National Laboratory," LANL report LA-12734-SR (1994).

Cross, S., "Aquatic Macroinvertebrates and Water Quality of Sandia Canyon, Los Alamos National Laboratory, November 1993 to October 1994," LANL report LA-12971-SR (1995).

Cross, S., "Aquatic Macroinvertebrates and Water Quality of Sandia Canyon, Los Alamos National Laboratory, 1995," LANL report LA-UR-96-3684 (1996a).

Cross, S., "Revised Biological Assessment and Floodplain/Wetland Assessment for the Low Energy Demonstration Accelerator, Technical Area 53," LANL report LA-UR-96$332(1996 b)$.

Daubenmire, R., "A Canopy-coverage Method of Vegetation Analysis," Northwestern Scientist 33: 43 - 64 (1959).

EPG: Environmental Protection Group, Environmental Surveillance at Los Alamos during 1994, LANL report LA-13047-ENV (July 1996).

Ehrlich, P. R., D. S. Dobbins, and D. Wheye, The Birder's Handbook, Simon and Schuster, Inc., New York (1988).

ESH-20, "Final Environmental Assessment for the Low Energy Demonstration Accelerator, Technical Area 53 , Los Alamos National Laboratory, Los Alamos, New Mexico," (1996). 
Foxx, T. S., and D. Hoard, Flower Plants of the Southwestern Forests, Otowi Crossing Press, Los Alamos, New Mexico (1995).

Gonzales, T. C., T. S. Foxx, and J. Biggs, "Analysis of Animal-Related Accidents in Los Alamos County," LANL report LA-UR-95-3950 (1995).

Heyer, W. R., M. A. Donnelly, R. W. McDiarmid, L. C. Hayek, and M. S. Foster, Measuring and Monitoring Biological Diversity: Standard Methods for Amphibians, Smithsonian Institution Press, Washington, D.C. (1994).

Hitchcock, A. S., and A. Chase, Manual of the Grasses of the United States, 2nd ed., Dover Publications, Inc., New York (1971).

Ivey, R. D., Flowering Plants of New Mexico, 3rd ed., Rio Rancho Printing, Rio Rancho, New Mexico (1995).

Martin, W. C., and C. R. Hutchins, A Flora of New Mexico, J. Cramer, Germany (1980).

National Geographic Society, "Field Guide to the Birds of North America," 2nd ed., published by the National Geographic Society (1987).

Schooley, R. L., and B. Van Horne, "Passive Integrated Transponders for Marking FreeRanging Small Mammals," Colorado State University (unpublished manuscript).

Shaull, D. A., M. R. Alexander, and R. P. Reynolds, "Surface Water Data at Los Alamos National Laboratory: 1995 Water Year," LANL report LA-13177-PR (1996).

State of New Mexico, "Standards for Interstate and Intrastate Streams," New Mexico Water Quality Control Commission, Santa Fe, New Mexico (1995)

Travis, J. R., Atlas of the Breeding Birds of Los Alamos County, Nev Mexico, Pajarito Ornithological Survey, LANL report LA-12206 (1992).

Vepraskas, M. J., "Redoximorphic Features for Identifying Aquic Conditions," North Carolina Agricultrual Research Service, North Carolina State University, Raleigh, N.C., Technical Bulletin 301 (1995).

WTI: Wetlands Training Institute, Inc., Field Guide for Wetland Delineation: 1987 Corps of Engineers Mamual, Poolesville, Md., WTI 95-3 (1995). 
APPENDIX A

\section{PLANT SPECIES FOUND WITHIN 1996 VEGETATION TRANSECTS IN MID-SANDIA CANYON}

\begin{tabular}{|c|c|c|}
\hline Scientific name & Common name & $\begin{array}{l}\text { Transec } \\
\text { number }\end{array}$ \\
\hline Ambrosia franceroides & ragweed & $1,2,3$ \\
\hline Artemisia carruthii & wormwood & $2,3,4$ \\
\hline Artemisia dracunculus & false tarragon & $1,2,3,4$ \\
\hline Artemisia ludoviciana & wormwood & 3,4 \\
\hline Bouteloua gracilis & blue grama & $1,2,3,4$ \\
\hline Bromus frondosus & weeping brome & $1,2,4$ \\
\hline Bromus inermis & smooth brome & 1 \\
\hline Bromus tectorum & downy chess & 2 \\
\hline Cearstium arvense & mouse-ear chickweed & 1 \\
\hline Chenopodium album & lamb's quarters & 3 \\
\hline Chrysothammus nauseosus & chamisa & 3,4 \\
\hline Conyza canadensis & horseweed & 1 \\
\hline Elymus trachycaulus & slender wheatgrass & $1,2,3$ \\
\hline Eriogomum jamesii & antelope sage & $2,3,4$ \\
\hline Erograstis mexicana & Mexican lovegrass & $1,2,3$ \\
\hline Helianthus petiolaris & prairie sunflower & 1 \\
\hline Ipomopsis aggregata & skyrocket & 3 \\
\hline Melitotus officianale & yellow sweet-clover & 1 \\
\hline Panicum capillare & witchgrass & 4 \\
\hline Pectis angustifolia & fetid-marigold & 1,4 \\
\hline Poa fendleriana & muttongrass & $1,3,4$ \\
\hline Portulaca oleracea & common purslane & 1,4 \\
\hline Robinia neomexican & New Mexico locust & 1 \\
\hline Sisymbrium altissiumum & tumble mustard & 2,4 \\
\hline
\end{tabular}




\begin{tabular}{|l|l|l|}
\hline \multicolumn{1}{|c|}{ Scientific name } & \multicolumn{1}{|c|}{ Common name } & \multicolumn{1}{c|}{$\begin{array}{c}\text { Transect } \\
\text { number }\end{array}$} \\
\hline Sporobolus cryptandrus & sand dropseed & $1,2,3,4$ \\
\hline Taraxacum officinale & dandelion & 1,3 \\
\hline Verbascum thapsus & mullein & $1,2,3$ \\
\hline Viguiera multiflora & goldeneye & $2,3,4$ \\
\hline Xanthium strumarium & cocklebur & 4 \\
\hline
\end{tabular}




\section{APPENDIX B}

BIRD SPECIES FOUND IN 1996 MID-SANDIA CANYON BIRD TRANSECT

\begin{tabular}{|c|c|c|c|}
\hline Scientific Name & Common Name & $\begin{array}{l}\text { Number of } \\
\text { Individuals }\end{array}$ & $\begin{array}{c}\text { Relative } \\
\text { abundance }\end{array}$ \\
\hline Turdus migratorius & American robin & 11 & $9.82 \%$ \\
\hline Myiarchus cinerascens & Ash-throated flycatcher & 5 & $3.57 \%$ \\
\hline Archilochus alexandri & Black-chinned hummingbird & 5 & $4.46 \%$ \\
\hline Vireo bellii & Bell's vireo & 1 & $0.89 \%$ \\
\hline Guiraca caerulea & Blue grosbeak & 3 & $2.68 \%$ \\
\hline Catherpes mexicamis & Canyon wren & 2 & $1.79 \%$ \\
\hline Spizella passerina & Chipping sparrow & 7 & $6.25 \%$ \\
\hline Empidonax wrightii & Gray flycatcher & 1 & $0.89 \%$ \\
\hline Carpodacus mexicamus & House finch & 4 & $3.57 \%$ \\
\hline Troglodytes aedon & House wren & 1 & $0.89 \%$ \\
\hline Carduelis psaltria & Lesser goldfinch & 8 & $7.14 \%$ \\
\hline Parus gambeli & Mountain chickadee & 7 & $6.25 \%$ \\
\hline Colaptes auratus & Northern flicker & 4 & $3.57 \%$ \\
\hline Mimus polyglottos & Nothern mockingbird & 2 & $1.79 \%$ \\
\hline Sitta pygmaea & Pygmy nuthatch & 13 & $11.61 \%$ \\
\hline Pipilo erthrophthalmus & Rufous-sided towhee & 7 & $6.25 \%$ \\
\hline Aphelocoma coerulescens & Scrub jay & 3 & $2.68 \%$ \\
\hline Vireo solitarius & Solitary vireo & 1 & $0.89 \%$ \\
\hline Vermivora virginiae & Virginia's warbler & 2 & $1.79 \%$ \\
\hline Tahycineat thalassina & Violet-green swallow & 4 & $3.57 \%$ \\
\hline Sialia mexicana & Western bluebird & 4 & $3.57 \%$ \\
\hline Tyrannus verticalis & Western kingbird & 4 & $3.57 \%$ \\
\hline Piranga ludociviana & Western tanager & 6 & $5.36 \%$ \\
\hline Contopus sordidulus & Western wood-pewee & 4 & $3.57 \%$ \\
\hline
\end{tabular}


1996 LEDA Anmual Biological Report, page 48 


\section{APPENDIX C}

REPTILES AND AMPHIBIAN SPECIES CAPTURED DURING

THE 1996 TRAPPING SEASON IN MID-SANDIA CANYON

\begin{tabular}{|l|l|c|c|}
\hline Scientific Name & Common Name & $\begin{array}{c}\text { Number of } \\
\text { Individuals }\end{array}$ & $\begin{array}{c}\text { Relative } \\
\text { Abundance }\end{array}$ \\
\hline Ambystoma tigrinum & Tiger salamander & 1 & $3.1 \%$ \\
\hline Cnemidophorus velox & Plateau striped whiptail & 6 & $18.8 \%$ \\
\hline Eumeces multivirgatus & Many-lined skink & 7 & $21.9 \%$ \\
\hline Sceloporus undulatus & Eastern fence lizard & 18 & $56.2 \%$ \\
\hline
\end{tabular}

